\title{
Stabilization of $\mathrm{BH}_{4}$ Group in Zinc Borohydride via Adduct of Ammonia towards a Pure Hydrogen Release
}

\author{
Liang Gao, ${ }^{a}$ Yanhui Guo, ${ }^{a}$ Kia Wallwork, ${ }^{b}$ Feiwu Zhang, ${ }^{c}$ Xuebin Yu ${ }^{* a}$
}

\begin{abstract}
${ }_{5} \mathrm{Zn}\left(\mathrm{BH}_{4}\right)_{2} \cdot 2 \mathrm{NH}_{3}$, a new ammine metal borohydride, has been synthesized via simply ball-milling a mixture of $\mathrm{ZnCl}_{2} \cdot 2 \mathrm{NH}_{3} / 2 \mathrm{LiBH}_{4}$. Structure analysis shows that the subsequent complex has a monoclinic structure with unit-cell parameters of $a=6.392(4) \AA, b=8.417(6) \AA, c=6.388(4) \AA$ and $\beta=92.407(4){ }^{\circ}$ and space group $P 2_{1}$, in which $\mathrm{Zn}$ atoms coordinate with two $\mathrm{BH}_{4}$ groups and two $\mathrm{NH}_{3}$ groups. The interatomic distances reported herein show that $\mathrm{Zn}-\mathrm{H}$ bonding in $\mathrm{Zn}\left(\mathrm{BH}_{4}\right)_{2} \cdot 2 \mathrm{NH}_{3}$ is shorter than Ca-H

10 bonds in $\mathrm{Ca}\left(\mathrm{BH}_{4}\right)_{2} \cdot 2 \mathrm{NH}_{3}$ and $\mathrm{Mg}-\mathrm{H}$ in $\mathrm{Mg}\left(\mathrm{BH}_{4}\right)_{2} \cdot 2 \mathrm{NH}_{3}$. This reduced bond contact leads to an increase in the ionic character of $\mathrm{H}$. This study is able to show a good correlation between the reduced $\mathrm{M}-\mathrm{H}$ distance and enhanced dehydrogenation behavior of the hydride material. Dehydrogenation results showed that this novel compound is able to release 8.9 wt. \% hydrogen below $115^{\circ} \mathrm{C}$ within 10 min without concomitant release of undesirable gases such as ammonia and/or boranes, thereby demonstrating 15 the potential of $\mathrm{Zn}\left(\mathrm{BH}_{4}\right)_{2} \cdot 2 \mathrm{NH}_{3}$ to be used as a solid hydrogen storage material.
\end{abstract}

\section{Introduction}

Hydrogen is considered one of the environmentally clean energy carriers, as it achieves nearly zero emission of pollutants from power generators, such as fuel cells. However, efforts to 20 make use of hydrogen as an on-board power source have been hampered by the safety concerns and volumetric constraints. ${ }^{1-4}$ In order for the wide-spread, practical use of hydrogen as an energy provider, it is necessary to store the gas in such a way as to achieve a high energy density, in addition it is important for 25 storage materials to be easily produced and subsequently used. Meeting these criteria will allow the efficient use of hydrogen storage materials. There is no doubt that if the hydrogen economy is to meet the practical application requirements then fundamental and applied research must provide the breakthrough in identifying 30 and understanding hydrogen-rich materials. ${ }^{5,6}$ Several metal borohydrides are known to provide high $\mathrm{H}_{2}$-capacity, however, issues such as: (1) high thermodynamic stability [e.g. high desorption temperature for $\mathrm{LiBH}_{4}$ or $\left.\mathrm{Mg}\left(\mathrm{BH}_{4}\right)_{2}\right]$, ${ }^{7,8}$ (2) thermodynamic instability [as seen in $\mathrm{Ti}\left(\mathrm{BH}_{4}\right)_{2}$ and $\left.\mathrm{Cu}\left(\mathrm{BH}_{4}\right)_{2}\right]^{9,10}$ 35 and (3) release of highly dangerous or toxic by-products, such as $\mathrm{BeH}_{2}, \mathrm{~B}_{2} \mathrm{H}_{6}\left[\mathrm{Be}\left(\mathrm{BH}_{4}\right)_{2}, \mathrm{Al}\left(\mathrm{BH}_{4}\right)_{3}\right.$ and $\left.\mathrm{Zn}\left(\mathrm{BH}_{4}\right)_{2}\right],{ }^{11-13}$ have thus far limited their success as suitable hydrogen storage candidates. It has been shown that there are ways in which to overcome these challenges, such as utilizing doping ${ }^{14}$ or the identification of 40 catalysis, $^{15}$ etc. Nevertheless, the utilization of additive agents imposes a penalty on hydrogen capacity to a level that is unacceptable for practical application. Thermodynamic modification of metal hydrides is considered to be an appropriate approach to reduce the operating temperature due to the driving ${ }_{45}$ force of $\mathrm{H}^{\delta+} / \mathrm{H}^{\delta-}$ combination. ${ }^{16}$ In recent years, such an approach has been widely adopted by different research groups to destabilize the $\mathrm{Li}(\mathrm{Mg}, \mathrm{Ca})-\mathrm{B}-\mathrm{N}-\mathrm{H}$ system; this has resulted in a significant decrease in the reaction enthalpy and a low dehydrogenation onset temperature compared to the individual 50 constituent. ${ }^{17,18}$

Ammonia borane $(\mathrm{AB})$ and its related compounds, are another series of materials generating intense interest as hydrogen sources. ${ }^{19}$ It is widely accepted that an attractive interaction between $\mathrm{H}^{\delta+}$ and $\mathrm{H}^{\delta-}$ is responsible for the hydrogen molecule 55 being desorbed at low temperature. ${ }^{19}$ More recently, ammine metal borohydrides (AMBs), another B-N-based hydride system, have been investigated with respect to their thermal decomposition properties, their crystalline structure and mechanism of $\mathrm{H}$-evolution. ${ }^{20-24}$ In AMBs, the ammonia is ${ }_{60}$ coordinated with the metal cation of borohydrides, which is similar to the ammine metal salts. ${ }^{25}$ The distinguished performance of AMBs regarding hydrogen storage can be ascribed to the combination of the $\mathrm{NH}_{3}$ group and the $\mathrm{BH}^{4-}$ anion on a molecular level. $\mathrm{NH}_{3}$ and $\mathrm{BH}^{4-}$ groups have a number of 65 favorable attributes including, a high hydrogen capacity, $17.6 \mathrm{wt}$. $\%$ for $\mathrm{NH}_{3}$ and 26.7 wt. $\%$ for $\mathrm{BH}^{4}$; and highly mobile $\mathrm{H} \delta+/ \mathrm{H} \delta$ atoms which may lead to a rapid generation of $\mathrm{H}_{2}$ and subsequent desorption at low temperature. ${ }^{26,} 27$ However, despite their promising characteristics, it has been observed that across a range 70 of AMBs they display a variety of different thermal decomposition properties. $\mathrm{LiBH}_{4} \cdot \mathrm{NH}_{3}$ and $\mathrm{Ca}\left(\mathrm{BH}_{4}\right)_{2} \cdot 2 \mathrm{NH}_{3}$ mainly release ammonia rather than hydrogen during decomposition in argon, which is attributed to the weak coordination between $\mathrm{Li}^{+}\left(\mathrm{Ca}^{2+}\right)$ with $\mathrm{NH}_{3}$ in the material. ${ }^{21,22}$ In 75 order to promote their dehydrogenation performance, chemical modification with various metal hydrides or metal chlorides or thermal decomposition under ammonia atmosphere are required. ${ }^{22,23} \mathrm{On}$ the contrary, $\mathrm{Mg}\left(\mathrm{BH}_{4}\right)_{2} \cdot 2 \mathrm{NH}_{3}$ and $\mathrm{Al}\left(\mathrm{BH}_{4}\right)_{3} \cdot 6 \mathrm{NH}_{3}$ and its double cation complex show dominant 80 hydrogen release upon heating. This is particularly true of the aluminum-based complexes ${ }^{20,24}$ which are able to release over $10 \%$ hydrogen below $150{ }^{\circ} \mathrm{C}$, exhibiting their potential as an advanced solid state hydrogen storage substrate. The above results strongly suggest that the dehydrogenation of AMBs is 85 dependent on the central metal cation(s), which affect the bonding properties between $\mathrm{BH}_{4}$ and $\mathrm{NH}_{3}$ and thus lead to different dehydrogenation behavior. Therefore, development of AMBs requires a better understanding of the crystal and electronic structures of the materials in order attempt targeted 90 design and to further improve characteristics such as the dehydrogenation temperature, purity of gas released, and 
thermodynamic properties.

Along with $\mathrm{Mg}^{2+}$ and $\mathrm{Al}^{3+}, \mathrm{Zn}^{2+}$ is also able to form strong coordination bonds with ammonia, which suggests potential for favorable dehydrogenation of ammonia complexes of the Zinc 5 borohydride system. ${ }^{28-31}$ As early as 1959 , zinc tetrahydroborate amines $\left(\mathrm{Zn}\left(\mathrm{BH}_{4}\right)_{2} \cdot 4 \mathrm{NH}_{3}\right)$ could be obtained from aqueousammoniacal solutions at low temperature by exchange reaction between the metal salts and sodium tetrahydroborate. ${ }^{31}$ However, to the best of our knowledge, there have been no reports on the 10 formation of $\mathrm{Zn}\left(\mathrm{BH}_{4}\right)_{2} \cdot 2 \mathrm{NH}_{3}$ and dehydrogenation properties of this class materials. In this paper, we report the synthesis and detailed structural, physical, and chemical characterization of the new ammine borohydride-based material $\mathrm{Zn}\left(\mathrm{BH}_{4}\right)_{2} \cdot 2 \mathrm{NH}_{3}$. Our results show that the dehydrogenation properties of ${ }_{15} \mathrm{Zn}\left(\mathrm{BH}_{4}\right)_{2} \cdot 2 \mathrm{NH}_{3}$ are significantly improved in terms of dehydrogenation temperature, hydrogen capacity, and the purity of gas released compared to the other reported ammine metal borohydrides. In addition, density functional theory results relating to this compound are compared to results from similar 20 calculations for $\mathrm{Ca}\left(\mathrm{BH}_{4}\right)_{2} \cdot 2 \mathrm{NH}_{3}$ and $\mathrm{Mg}\left(\mathrm{BH}_{4}\right)_{2} \cdot 2 \mathrm{NH}_{3}$ and hydrogen release properties of these materials are discussed.

\section{Experimental}

\section{Sample and equipments}

$\mathrm{LiBH}_{4}$ (95\%, J\&K Co. Ltd), liquid anhydrous ammonia 25 (99.999\%, Sinopharm Chemical Reagent Co. Ltd) and anhydrous $\mathrm{ZnCl}_{2}$ (99.99\%, Sigma Aldrich Co. Ltd) were all sourced commercially. In order to produce pure $\mathrm{ZnCl}_{2} \cdot 2 \mathrm{NH}_{3}$, $\mathrm{ZnCl}_{2} \cdot 6 \mathrm{NH}_{3}$ was pre-fabricated by exposing $\mathrm{ZnCl}_{2}$ powder in 1 atm ammonia for 24 hours and then thermally decomposing the 30 product to $\mathrm{ZnCl}_{2} \cdot 2 \mathrm{NH}_{3}$ and $\mathrm{NH}_{3}$ under Ar flow at $150{ }^{\circ} \mathrm{C}$. The composition of $\mathrm{ZnCl}_{2} \cdot 2 \mathrm{NH}_{3}$ was identified by gravimetry. XRD results (Figure S1) revealed that the synthesized $\mathrm{ZnCl}_{2} \cdot 2 \mathrm{NH}_{3}$ structure is orthorhombic (space group Imam) with lattice parameters $\mathrm{a}=7.7025(2) \AA, \mathrm{b}=8.1005(3) \AA$ and $\mathrm{c}=8.5051(3)$ ${ }_{35} \AA$, which is consistent with that reported in literature. ${ }^{32}$ $\mathrm{Zn}\left(\mathrm{BH}_{4}\right)_{2} \cdot 2 \mathrm{NH}_{3}$ was prepared by milling the mixture of $\mathrm{LiBH}_{4}$ and $\mathrm{ZnCl}_{2} \cdot 2 \mathrm{NH}_{3}$ in a 2:1 molar ratio for $60 \mathrm{~min}$ (planetary QM$1 \mathrm{SP} 2$ ) at $400 \mathrm{rpm}$ under argon using stainless steel spheres with a BPR of 60:1. The milling process was carried out alternating 6 $40 \mathrm{~min}$ of milling and $6 \mathrm{~min}$ of rest in order to avoid an unacceptable increase in the temperature of the powders in the vial. By way of comparison, $\mathrm{ZnCl}_{2} / 2 \mathrm{LiBH}_{4}$ was also processed under the same conditions as described above. All handling of the powders before and after milling were carried out in a glove box 45 containing an argon atmosphere. Gas release property measurements were performed by thermogravimetry analysis connected to a mass spectrometer (TGA-MS), using a heating rate of $10{ }^{\circ} \mathrm{C} \mathrm{min}^{-1}$ under $1 \mathrm{~atm}$ Nitrogen with a purge rate of 200 $\mathrm{cm}^{3} \mathrm{~min}^{-1}$. To identify all possible gaseous products, survey scans
50 in the mass range of $2-80 \mathrm{amu}$ were recorded from the two samples. The temperature dependence of desorption/decomposition was monitored by a Sievert's temperature-programmed-desorption (TPD) under 1 atm argon.

High-resolution X-ray powder diffraction data were collected ${ }_{55}$ from $\mathrm{Zn}\left(\mathrm{BH}_{4}\right)_{2} \cdot 2 \mathrm{NH}_{3}$ samples at the Australian Synchrotron powder diffraction beamline, ${ }^{33}$ using the Mythen-II detector. ${ }^{34}$ For phase identification and structure determination, the sample was loaded into a pre-dried $0.5 \mathrm{~mm}$ special-glass capillary whilst inside an Argon-filled glove box. The capillary was sealed with 60 vacuum grease for X-ray diffraction measurements. High temperature in-situ XRD were conducted using a Cyberstar hot air blower at a heating rate of $3{ }^{\circ} \mathrm{C} \mathrm{min}^{-1}$; and data were collected over the temperature range 25 to $430{ }^{\circ} \mathrm{C}$, in steps of $5{ }^{\circ} \mathrm{C}$. For insitu high temperature measurements, the sample was loaded into 65 a $0.7 \mathrm{~mm}$ quartz capillary and mounted in a gas flow-cell in order to maintain an argon atmosphere over the sample throughout the experiment. Data were collected for all measurements at a wavelength of $0.8260 \AA$, determined through the use of NIST standard LaB6 660a. Solid-state infrared spectra of the samples 70 (as $\mathrm{KBr}$ pellets) were recorded on a Nicolet Nexus 470 in the range of $300 \mathrm{~cm}^{-1}$ to $4000 \mathrm{~cm}^{-1}$. During the IR measurement, samples were loaded into a sealed tube with $\mathrm{CaF}_{2}$ windows. Solid-state ${ }^{11}$ B NMR data were recorded (DSX 300) using a Doty CP-MAS probe with no probe background. All of those solid 75 samples were spun at $12 \mathrm{kHz}$, using $4 \mathrm{~mm} \mathrm{ZrO}_{2}$ rotors filled under a purified argon atmosphere within a glove box. A $0.55 \mu \mathrm{s}$ single-pulse excitation was employed, with repetition times of 1.5 s. Differential scanning calorimetry (DSC) was performed by netzsch 204HP DSC under argon with a gas flow of $20 \mathrm{ml} \mathrm{min}^{-1}$ 80 at a heating rate of $10 \mathrm{~K} \mathrm{~min}^{-1}$. The $\mathrm{N}$ and $\mathrm{H}$ elemental analyses were performed using an Elementar Vario EL-III instrument. The isothermal dehydrogenation performances of the samples were examined by TPD apparatus with typical sample weigh of $90 \mathrm{mg}$. For comparison, the TG and TPD results relative to the pure ${ }_{85} \mathrm{Zn}\left(\mathrm{BH}_{4}\right)_{2} \cdot 2 \mathrm{NH}_{3}$ are also showed in this study.

\section{Sample and equipments}

The geometries of $\mathrm{Me}\left(\mathrm{BH}_{4}\right)_{2} \cdot 2 \mathrm{NH}_{3}(\mathrm{Me}=\mathrm{Zn}, \mathrm{Ca}$ or $\mathrm{Mg})$ have been optimized by first principles calculations with the CASTEP code ${ }^{35,36}$ based on density functional theory (DFT). The Perdew ${ }_{90}$ Burke Ernzerhof (PBE) functional was used with the generalized gradient approximation (GGA) for all calculations. ${ }^{37}$ The ultrasoft pseudopotentials that we used have the valence-electron configurations of $1 \mathrm{~s}^{1}$ (core radius $0.8 \mathrm{a}$. u.) for $\mathrm{H}, 2 \mathrm{~s}^{2} 2 \mathrm{p}^{1}$ (core radius 1.4 a. u.) for $\mathrm{B}, 2 \mathrm{~s}^{2} 2 \mathrm{p}^{3}$ (core radius 1.4 a. u.) for $\mathrm{N}, 3 \mathrm{~d}^{10} 4 \mathrm{~s}^{2}$ 95 (core radius 2.0 a. u.) for $\mathrm{Zn}, 2 \mathrm{p}^{6} 3 \mathrm{~s}^{2}$ (core radius 2.06 a. u.) for $\mathrm{Mg}$ and $3 \mathrm{~S}^{2} 2 \mathrm{p}^{6} 4 \mathrm{~S}^{2}$ (core radius 1.6 a. u.) for $\mathrm{Ca}$. The initial $\mathrm{Me}\left(\mathrm{BH}_{4}\right)_{2} \cdot 2 \mathrm{NH}_{3}$ structures for optimization were taken from the $\mathrm{X}$-ray refinement data directly. We have used the plane-wave cutoff of $500 \mathrm{eV}$ for representing the wave functions and 4 x 3 x $4 \mathrm{k}$ - 



point grid (i.e. $24 \mathrm{k}$-points) for the Brillouin zone sampling by the Monkhorst-Pack scheme. Geometry optimizations were performed using the BFGS procedure 38 at $0 \mathrm{~K}$. The energy tolerance was $5 \times 10^{-6} \mathrm{eV} /$ atom; the maximum tolerance for force

the structure of $\mathrm{Zn}\left(\mathrm{BH}_{4}\right)_{2} \cdot 2 \mathrm{NH}_{3}$ which has been solved by synchrotron radiation powder $\mathrm{X}$-ray diffraction. (Structural data 35 and atomic position are summarized in Table S1-S3, respectively). Bragg peaks in the room temperature diffraction

Fig. 1 Illustrations of the $\mathrm{Zn}\left(\mathrm{BH}_{4}\right)_{2} \cdot 2 \mathrm{NH}_{3}$ structure: (a) 'molecular' fragment; and (b) $2 \times 2 \times 2$ unit cell projected down the $c$-axis.

5 and atom displacements along any Cartesian component was 0.01 $\mathrm{eV} / \AA$ and $5 \times 10^{-4} \AA$, respectively. These parameters lead to a satisfactory convergence of the total energy. Geometry optimization was conducted in this study with the full optimization. The calculated structure files (ZnBNH-2-opt.cif) 10 are attached in the supplementary information. The fullyoptimized structure was selected for further exploration and was used to calculate density of states (DOS) and the electron localization function (ELF) information.

\section{Results and discussions}

\section{${ }_{15}$ Synthesis and Crystal structure determination}

Our proposal to synthesize $\mathrm{Zn}\left(\mathrm{BH}_{4}\right)_{2}\left(\mathrm{NH}_{3}\right)_{2}$ stems from the early report regarding $\mathrm{Zn}\left(\mathrm{BH}_{4}\right)_{2}$ preparation by solution chemistry: ${ }^{12(b), 39}$

$20 \mathrm{Na}$ )

$2 \mathrm{MBH}_{4}+\mathrm{ZnCl}_{2} \stackrel{\mathrm{Et}_{2} \mathrm{O}}{\longrightarrow} \mathrm{Zn}\left(\mathrm{BH}_{4}\right)_{2}+2 \mathrm{MCl} \quad$ (1) $\quad(\mathrm{M}=\mathrm{K}, \mathrm{Li}$ or

Given $\mathrm{Zn}^{2+}$ in $\mathrm{Zn}\left(\mathrm{BH}_{4}\right)_{2}$ is a soft Lewis acid as compared to alternatives such as $\mathrm{Li}^{+}$, and $\mathrm{Na}^{+}$which are hard acids, ${ }^{12(b)}$ the desired metathesis reaction should occur by substituting the starting material of $\mathrm{ZnCl}_{2}$ in Eqn. (1) with $\mathrm{ZnCl}_{2} \cdot 2 \mathrm{NH}_{3}$, as 25 described in Eqn. (2).

$\mathrm{ZnCl}_{2} \cdot 2 \mathrm{NH}_{3}+2 \mathrm{LiBH}_{4}$

ball milling

$\mathrm{Zn}\left(\mathrm{BH}_{4}\right)_{2} \cdot 2 \mathrm{NH}_{3}+2 \mathrm{LiCl}$ (2)

The product of this reaction has been verified by XRD, FTIR and element analysis $(\mathrm{N}, \mathrm{H})$. Elemental analysis confirms that 30 there is no appreciable change in the ratio of $\mathrm{N}$ to $\mathrm{H}$ (before ball milling, $\mathrm{N}: \mathrm{H}=1: 7$; and after ball milling, $\mathrm{N}: \mathrm{H}=1: 6.65$ ), indicating no loss of $\mathrm{NH}_{3}$ sources during the ball milling. This study reports patterns from the sample were indexed to a monoclinic unit cell using the program DICVOL. ${ }^{40}$ The space group $P 2_{1}$ and $P 2_{1} / \mathrm{m}$ can be assigned based on systematic absences. The structure was 40 subsequently solved in the space group of $P 2_{1}$ (No. 4) by global optimization in direct space, using the program FOX. ${ }^{41}$ Rietveld refinement was performed using TOPAS v4.2, ${ }^{42}$ and the refined lattice parameters are $a=6.392(4) \AA, b=8.417$ (6) $\AA, c=$ $6.388(4) \AA, \beta=92.407(4)^{\circ}$. The diffraction profile fit using these 45 parameters is shown in Figure S2; the Rietveld fit line and differences between the experimental and calculated values are visible.

The structure of $\mathrm{Zn}\left(\mathrm{BH}_{4}\right)_{2} \cdot 2 \mathrm{NH}_{3}$, as shown in Figure 1, can be described as comprising discrete units of $\mathrm{Zn}\left(\mathrm{BH}_{4}\right)_{2} \cdot 2 \mathrm{NH}_{3}$ where 50 zinc cations are coordinated by $2 \mathrm{NH}_{3}$ and $2 \mathrm{BH}_{4}$, similar to the interactions observed in $\mathrm{Mg}\left(\mathrm{BH}_{4}\right)_{2} \cdot 2 \mathrm{NH}_{3}$ where the structure is described as essentially molecular. ${ }^{20}$ The observed average $\mathrm{Zn}-\mathrm{N}$ distance, of $2.13 \AA$, is a little longer than that in $\mathrm{ZnCl}_{2} \cdot 2 \mathrm{NH}_{3}$ at $2.02 \AA^{32}$ The difference in the structures of these two complexes ${ }_{55}$ is evidently not caused by steric factors (the ionic radius of the $\mathrm{BH}_{4}^{-}$group is close to that of $\mathrm{Cl}^{-}$) but rather the possible formation of $\mathrm{Cl}-\mathrm{N}$ hydrogen bonds in the latter. ${ }^{43}$ The $\mathrm{Zn}-\mathrm{B}$ average distance of $2.32 \AA$ is quite close to the corresponding contact in $\mathrm{Mg}\left(\mathrm{BH}_{4}\right)_{2} \cdot 2 \mathrm{NH}_{3}(2.39 \AA)$ for the pseudotetrahedral ${ }_{60}$ coordinated $\mathrm{Mg}$ atom. $^{20}$ In addition, the packing of $\mathrm{Zn}\left(\mathrm{BH}_{4}\right)_{2} \cdot 2 \mathrm{NH}_{3}$ is highly consistent with that observed in $\mathrm{Mg}\left(\mathrm{BH}_{4}\right)_{2} \cdot 2 \mathrm{NH}_{3}$, the $\mathrm{N}_{2}$ edge of one molecule faces one $\mathrm{B}$ atom of another molecule. These interactions lead to the arrangement of the $\mathrm{Zn}\left(\mathrm{BH}_{4}\right)_{2} \cdot 2 \mathrm{NH}_{3}$ molecules into pseudo-layers 65 perpendicular to the $a$ axis. The $\mathrm{Zn}-\mathrm{H}$ bonds in $\mathrm{Zn}\left(\mathrm{BH}_{4}\right)_{2} \cdot 2 \mathrm{NH}_{3}$, at $1.9 \AA$, are shorter by $c a .0 .2 \AA$, than those reported for the 


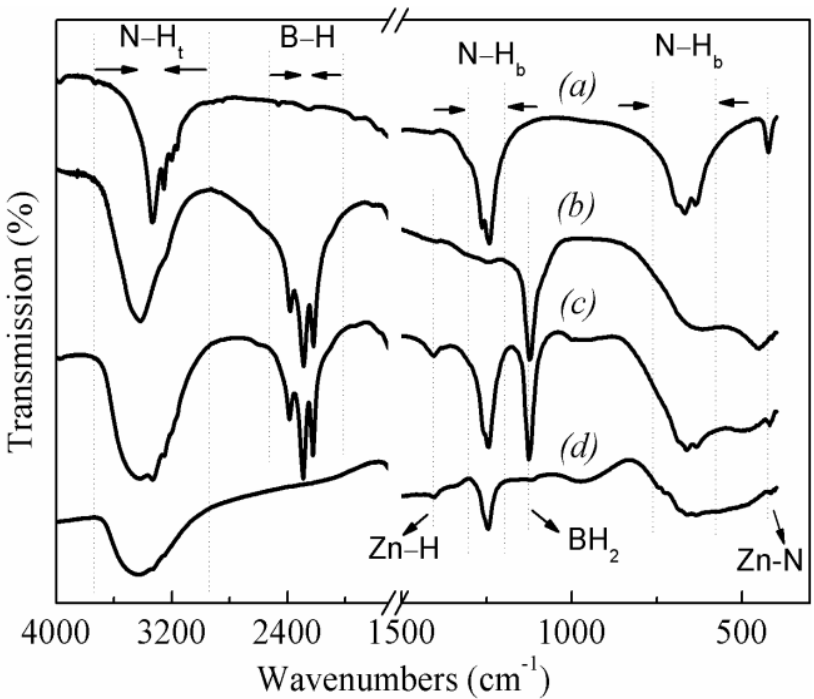

Fig. 2 FTIR spectra from reagents (a) $\mathrm{ZnCl}_{2} \cdot 2 \mathrm{NH}_{3}$ and (b) pure $\mathrm{LiBH}_{4}$. FTIR spectra from the product (c) post-milled $\mathrm{ZnCl}_{2} \cdot 2 \mathrm{NH}_{3} / 2 \mathrm{LiBH}_{4}$ and (d) post-heated $\mathrm{ZnCl}_{2} \cdot 2 \mathrm{NH}_{3} / 2 \mathrm{LiBH}_{4}$. Regions of the spectra have been marked to denote relevant features pertaining to the structures.
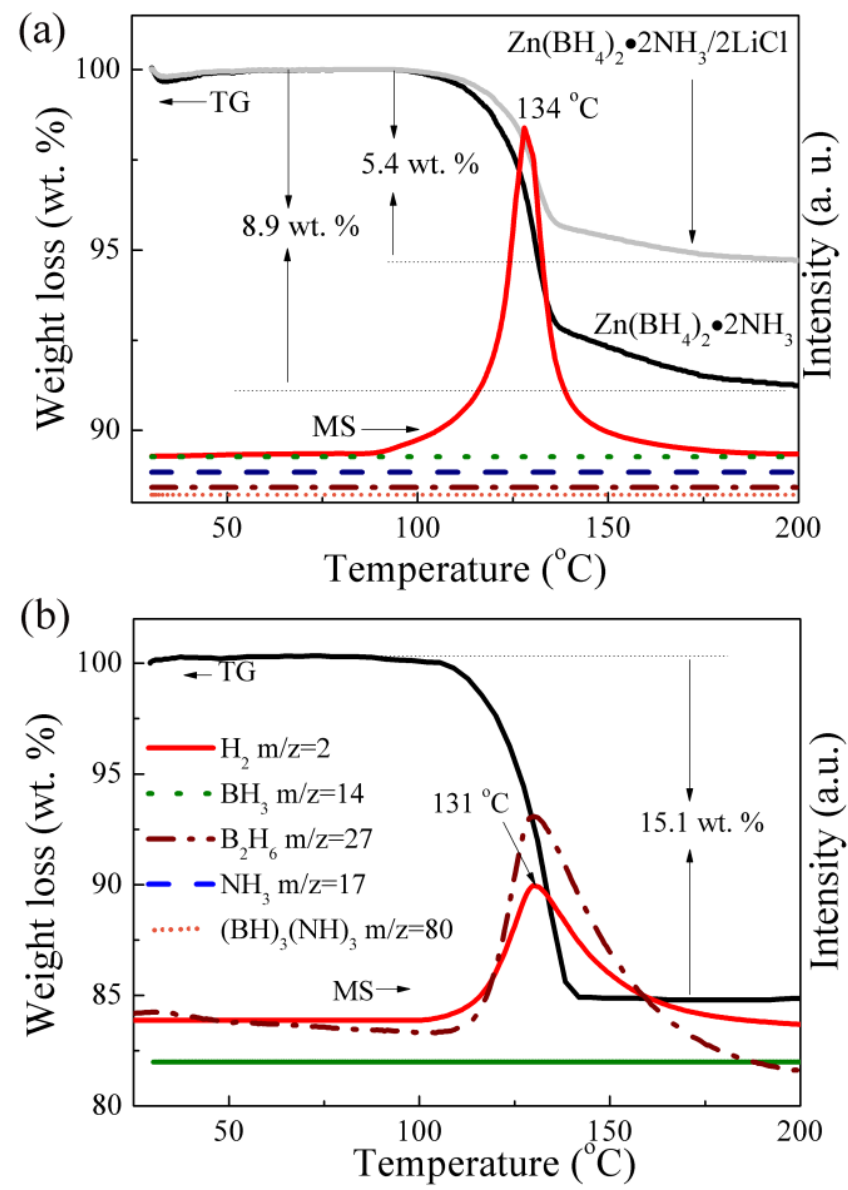

Fig. 3 TG-MS profiles for the as-prepared $\mathrm{Zn}\left(\mathrm{BH}_{4}\right)_{2} \cdot 2 \mathrm{NH}_{3}$ (a) and $2 \mathrm{LiBH}_{4} / \mathrm{ZnCl}_{2}$ (b). For comparison, the TG results relative to the $\mathrm{Zn}\left(\mathrm{BH}_{4}\right)_{2} \cdot 2 \mathrm{NH}_{3} / 2 \mathrm{LiCl}$ and pure $\mathrm{Zn}\left(\mathrm{BH}_{4}\right)_{2} \cdot 2 \mathrm{NH}_{3}$ are showed in (a), respectively).

$\mathrm{Zn}_{2}\left(\mathrm{BH}_{4}\right)_{5}{ }^{-}$ion. ${ }^{39}$ This observation is supported by FTIR data as shown in Figure S3, which also shows a formed weakening of the $\mathrm{Zn}-\mathrm{H}$ bond relative the reported $\mathrm{Zn}-\mathrm{H}$ bond in $\mathrm{Zn}\left(\mathrm{BH}_{4}\right)_{2}$. Such weakening may be caused by the steric effects of $\mathrm{NH}_{3}$ group in ${ }_{5} \mathrm{Zn}\left(\mathrm{BH}_{4}\right)_{2} \cdot 2 \mathrm{NH}_{3}$. Furthermore, the much shorter $\mathrm{H}-\mathrm{H}$ distances (1.91-2.31 A, Table S4) from $\mathrm{Zn}\left(\mathrm{BH}_{4}\right)_{2} \cdot 2 \mathrm{NH}_{3}$ suggest the formation of dihydrogen bonding as addressed in other AMBs compounds. $^{20-23}$ As shown in Figure 1c, d, e, and $\mathrm{f}$, $\mathrm{Zn}\left(\mathrm{BH}_{4}\right)_{2} \cdot 2 \mathrm{NH}_{3}$ comprises $\mathrm{H}^{\delta+}$ from $\mathrm{NH}_{3}$ units and $\mathrm{H}^{\delta-}$ from $\mathrm{BH}_{4}$ 10 units indicating the high possibility to possess of strongly hybridized valence electrons or closed shell bonds between B-H and between $\mathrm{N}-\mathrm{H}$, which can be primarily responsible for stability of this structure at room temperature. The strong $\mathrm{NH} \cdots \mathrm{HB}$ interaction in $\mathrm{Zn}\left(\mathrm{BH}_{4}\right)_{2} \cdot 2 \mathrm{NH}_{3}$ structure is also expected 15 to have a great impact on improving the dehydrogenation performance.

It is reported that the preparation of neat $\mathrm{Zn}(\mathrm{BH})_{4}$ using dry chemistry such as ball milling can be hindered by the tendency toward formation of mixed-cation ( $\mathrm{Zn}-\mathrm{Li}$ or $\mathrm{Zn}-\mathrm{Na}$ ) ${ }_{20}$ borohydrides. ${ }^{44} \mathrm{By}$ analogy, it is also possible for the formation of $\mathrm{LiZn}\left(\mathrm{BH}_{4}\right)_{3} \cdot 2 \mathrm{NH}_{3}$ in the reaction of Eqn.(2). We tried to solve the structure on both $\mathrm{LiZn}\left(\mathrm{BH}_{4}\right)_{3} \cdot 2 \mathrm{NH}_{3}$ and $\mathrm{Zn}\left(\mathrm{BH}_{4}\right)_{2} \cdot 2 \mathrm{NH}_{3}$ chemical formula with all possible space groups with the relatively small volume $\left(343.4 \AA^{3}\right)$. However, with ${ }_{25} \mathrm{LiZn}\left(\mathrm{BH}_{4}\right)_{3} \cdot 2 \mathrm{NH}_{3}$ composition, the additional $\mathrm{Li}$ atom and $\mathrm{BH}_{4}$ group can not fit into the indexed monoclinic unit cell with overestimated density. In addition, if the final product is the formation of $\mathrm{LiZn}\left(\mathrm{BH}_{4}\right)_{3} \cdot 2 \mathrm{NH}_{3}, \mathrm{ZnCl}_{2} \cdot 2 \mathrm{NH}_{3}$ would be excessive. However, form the XRD results, no $\mathrm{ZnCl}_{2} \cdot 2 \mathrm{NH}_{3}$ can be identified 30 after ball milling (Figure S2). These results indirectly confirm that the formed ammoniate is the $\mathrm{Zn}\left(\mathrm{BH}_{4}\right)_{2} \cdot 2 \mathrm{NH}_{3}$ rather than $\mathrm{LiZn}\left(\mathrm{BH}_{4}\right)_{3} \cdot 2 \mathrm{NH}_{3}$.

To improve the knowledge about the chemical bond information of $\mathrm{Zn}\left(\mathrm{BH}_{4}\right)_{2} \cdot 2 \mathrm{NH}_{3}$, we have carefully examined this 35 new phase by FTIR spectroscopy, before and after heat treatment, and have also obtained FTIR data from the reagents, $\mathrm{ZnCl}_{2} \cdot 2 \mathrm{NH}_{3}$ and $\mathrm{LiBH}_{4}$, for comparison (Figure 2). Features in the spectra pertaining to the starting materials are evident in the spectrum recorded from the post-milled sample, suggesting that both $\mathrm{B}$ and ${ }_{40} \mathrm{~N}$ atoms are still in the integral ligation pattern $\mathrm{BH}_{4}^{-}$and $\mathrm{NH}_{3}$ group. ${ }^{39}$ Thus, although it is normally believed that it is not possible to locate $\mathrm{H}$-atom positions from powder XRD data, this FTIR information, which is highly consistent with original $\mathrm{NH}_{3}$ and $\mathrm{BH}_{4}$, lend credence to the rigid body modeling of $\mathrm{BH}_{4}{ }^{-}$and ${ }_{45} \mathrm{NH}_{3}$ groups. Moreover, $\mathrm{Zn}-\mathrm{N}$ bonding can be clearly observed in Figure 2c, following milling, at the same wavenumber as in $\mathrm{ZnCl}_{2} \cdot 2 \mathrm{NH}_{3}$, implying that the Lewis acid to which $\mathrm{NH}_{3}$ coordinates is still $\mathrm{Zn}^{2+}$. The bond length, as determined by powder diffraction is longer in $\mathrm{Zn}\left(\mathrm{BH}_{4}\right)_{2} \cdot 2 \mathrm{NH}_{3}$ (at ca. $2.13 \AA$ ) 50 compared to that in $\mathrm{ZnCl}_{2} \cdot 2 \mathrm{NH}_{3}$ (at $2.02 \AA$ ), ${ }^{32}$ agreeing well with the decreasing intensity of $\mathrm{IR}$ absorption following milling. Notably, after ball milling of $\mathrm{ZnCl}_{2} \cdot 2 \mathrm{NH}_{3}$ and $\mathrm{LiBH}_{4}$, the appearance of a weak peak observed in $1409 \mathrm{~cm}^{-1}$ (nearly exactly

55 the position of the reported $\mathrm{Zn}-\mathrm{H}$ vibration, see Figure S3) ${ }^{39}$ suggests that, by mechanochemical reaction, $\mathrm{BH}_{4}^{-}$transfers from $\mathrm{LiBH}_{4}$ to combine with $\mathrm{Zn}^{2+}$ and engages in a substitution reaction with $\mathrm{Cl}^{-}$. The above results directly confirm some key information about $\mathrm{Zn}\left(\mathrm{BH}_{4}\right)_{2} \cdot 2 \mathrm{NH}_{3}$, namely, that both the $\mathrm{BH}_{4}{ }^{-}$ 


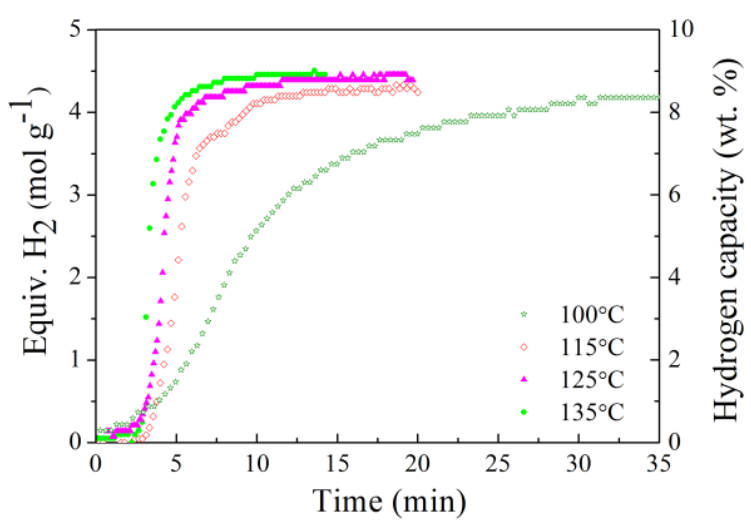

Fig. 4 Isothermal curves for hydrogen desorption of $\mathrm{Zn}\left(\mathrm{BH}_{4}\right)_{2} \cdot 2 \mathrm{NH}_{3}$ at various temperatures. The results are calculated relative to the pure $\mathrm{Zn}\left(\mathrm{BH}_{4}\right)_{2} \cdot 2 \mathrm{NH}_{3}$.

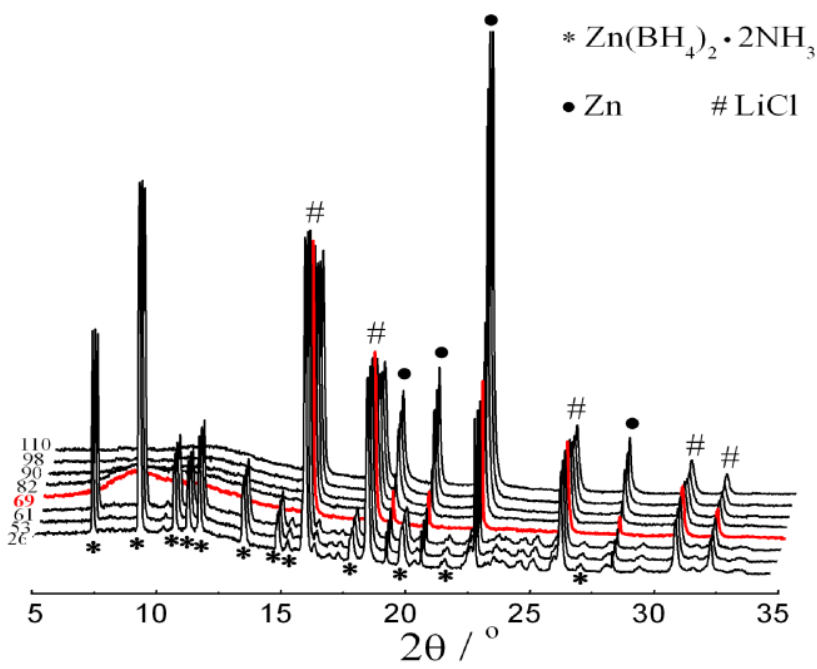

Fig. 5 In-situ variable temperature high resolution powder XRD data collected from $\mathrm{Zn}\left(\mathrm{BH}_{4}\right)_{2} \cdot 2 \mathrm{NH}_{3}$. The compound was heated to selected temperatures at fine temperature steps. Asterisks (*) mark the position of $\mathrm{Zn}\left(\mathrm{BH}_{4}\right)_{2} \cdot 2 \mathrm{NH}_{3}$ diffraction peaks, peaks relating to impurities are also indicated.

and the ligand $\mathrm{NH}_{3}$ subunits remain intact in the new structure; and $\mathrm{Zn}^{2+}$ is observed to have bonded with both the $\mathrm{NH}_{3}$ and $\mathrm{BH}_{4}$ groups.

\section{Dehydrogenation performance and pathway}

5 In order to emphasize the positive effect of the coordinated $\mathrm{NH}_{3}, \mathrm{ZnCl}_{2} / 2 \mathrm{LiBH}_{4}$ was milled together under the same condition as $\mathrm{ZnCl}_{2} \cdot 2 \mathrm{NH}_{3} / 2 \mathrm{LiBH}_{4}$ and laboratory XRD data were acquired to confirm the identity of the synthesized phase (see Figure S4). According to the previous literatures, the ball milled 10 products of $\mathrm{ZnCl}_{2} / 2 \mathrm{LiBH}_{4}$ turn out to be a mixed-metal $(\mathrm{Zn}-\mathrm{Li})$ borohydride $\left(\mathrm{ZnLi}\left(\mathrm{BH}_{4}\right)_{3}\right) .{ }^{44}$ Figure 3 shows the thermal decomposition performance of the as-prepared $\mathrm{Zn}\left(\mathrm{BH}_{4}\right)_{2} \cdot 2 \mathrm{NH}_{3}$ compared to the as-prepared $\mathrm{ZnLi}\left(\mathrm{BH}_{4}\right)_{3}$. As seen from the mass spectrometry (MS) profiles(Figure 3a), the $\mathrm{H}_{2}$ desorption from
${ }_{15} \mathrm{Zn}\left(\mathrm{BH}_{4}\right)_{2} \cdot 2 \mathrm{NH}_{3}$ starts at around $90{ }^{\circ} \mathrm{C}$ and ends before $150{ }^{\circ} \mathrm{C}$ with one peak centered at $127^{\circ} \mathrm{C}$, and no ammonia, boranes and borazine impurities were detected throughout the heating. By contrast, the MS results of the ball milled $\mathrm{ZnCl}_{2} / 2 \mathrm{LiBH}_{4}$ confirm that a significant volume of diborane, $\mathrm{B}_{2} \mathrm{H}_{6}$, accompanies the 20 evolution of $\mathrm{H}_{2}$, leading to a large mass loss of 15.1 wt.\% (Figure $3 b$ ). Furthermore, the quantity of $\mathrm{H}_{2}$ released (about 5.7 equiv., see Figure S5) before $200{ }^{\circ} \mathrm{C}$ determined by volumetric measurement agrees very well with the value calculated based

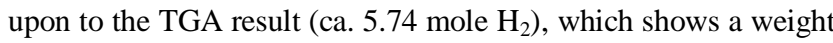
25 loss of 8.9 wt.\% for pure $\mathrm{Zn}\left(\mathrm{BH}_{4}\right)_{2} \cdot 2 \mathrm{NH}_{3}$ (accounting for 5.36 wt.\% in $\mathrm{Zn}\left(\mathrm{BH}_{4}\right)_{2} \cdot 2 \mathrm{NH}_{3} / 2 \mathrm{LiCl}$ mixture). Clearly, the adduct of $\mathrm{NH}_{3}$ plays a crucial role in ensuring the purity of $\mathrm{H}_{2}$ and suppressing $\mathrm{B}_{2} \mathrm{H}_{6}$ release. Furthermore, the dehydrogenation of $\mathrm{Zn}\left(\mathrm{BH}_{4}\right)_{2} \cdot 2 \mathrm{NH}_{3}$ was investigated using isothermal volumetric 30 hydrogen release measurements at various temperatures. As shown in Figure 4, approximately 5.5 equiv. hydrogen can be released within $35 \mathrm{~min}$ at $100{ }^{\circ} \mathrm{C}$, suggesting favorable kinetics for this hydrogen storage material. Using increasing temperatures, from $115^{\circ} \mathrm{C}$ to $135^{\circ} \mathrm{C}$, hydrogen release time can 35 be reduced from $15 \mathrm{~min}$ to $10 \mathrm{~min}$, respectively. This faster release is accompanied by an increase in the volume of hydrogen released, to $c a$. 5.7 equiv. hydrogen, corresponding to 8.9 wt.\% at $115^{\circ} \mathrm{C}$.

The differential scanning calorimetry (DSC) results from the 40 thermal decomposition of $\mathrm{Zn}\left(\mathrm{BH}_{4}\right)_{2} \cdot 2 \mathrm{NH}_{3}$ (Figure S6) reveal that the decomposition is preceded by one small endothermic signal which occurs without any mass loss between $72-90{ }^{\circ} \mathrm{C}$, originating from the melting of $\mathrm{Zn}\left(\mathrm{BH}_{4}\right)_{2} \cdot 2 \mathrm{NH}_{3}$. This melt point was visually confirmed by heating $\mathrm{Zn}\left(\mathrm{BH}_{4}\right)_{2} \cdot 2 \mathrm{NH}_{3}$ in an Argon 45 filled transparent vial. A maximum exothermic peak appeared at ca. $131{ }^{\circ} \mathrm{C}$, corresponding to the release of hydrogen. Integration of the differential heat in the range of $90-160{ }^{\circ} \mathrm{C}$ yields a heat of decomposition of approximately $-15 \mathrm{~kJ} \mathrm{~mol}^{-1} \mathrm{H}_{2}$, which is lower than that of $\mathrm{AB}\left(-21 \mathrm{~kJ} \mathrm{~mol}^{-1} \mathrm{H}_{2}\right){ }^{45}$ Although the exothermic 50 dehydrogenation of $\mathrm{Zn}\left(\mathrm{BH}_{4}\right)_{2} \cdot 2 \mathrm{NH}_{3}$ suggests that a direct reversibility of rehydrogenation from the decomposed products is infeasible, recent results on the reversible rehydrogenation via a chemical route conducted in $\mathrm{AB}$ system $^{46}$ illuminate the possibility of a more feasible chemical reversibility of ${ }_{55} \mathrm{Zn}\left(\mathrm{BH}_{4}\right)_{2} \cdot 2 \mathrm{NH}_{3}$ due to its lower exothermicity than $\mathrm{AB}$ upon decomposition.

From the in-situ X-ray diffraction data shown in Figure 5, the changes undergone by the sample are reflected in the diffraction data and can be correlated to melting and $\mathrm{H}_{2}$ desorption observed 60 in the MS and DSC results. At $26{ }^{\circ} \mathrm{C}$, the as-prepared $\mathrm{Zn}\left(\mathrm{BH}_{4}\right)_{2} \cdot 2 \mathrm{NH}_{3}$ can be clearly identified with intense and sharp Bragg diffraction peaks in the angle range of 5-30 degrees, indicative of long-range crystalline order of the material. Aside from the presence of $\mathrm{LiCl}$, which is a by-product of ${ }_{65} \mathrm{Zn}\left(\mathrm{BH}_{4}\right)_{2} \cdot 2 \mathrm{NH}_{3}$ synthesis, a number of peaks with relatively weak intensity relating to $\mathrm{Zn}$ are also observed; these suggest the fractional decomposition of $\mathrm{Zn}\left(\mathrm{BH}_{4}\right)_{2} \cdot 2 \mathrm{NH}_{3}$ due to the ball milling. Fractional decomposition is supported by ${ }^{11} \mathrm{~B}$ NMR results which show small B-N-H peaks (see Figure S7). As the 70 temperature increases during the diffraction experiment the data reveal an abrupt absence of $\mathrm{Zn}\left(\mathrm{BH}_{4}\right)_{2} \cdot 2 \mathrm{NH}_{3}$ and the presence of 


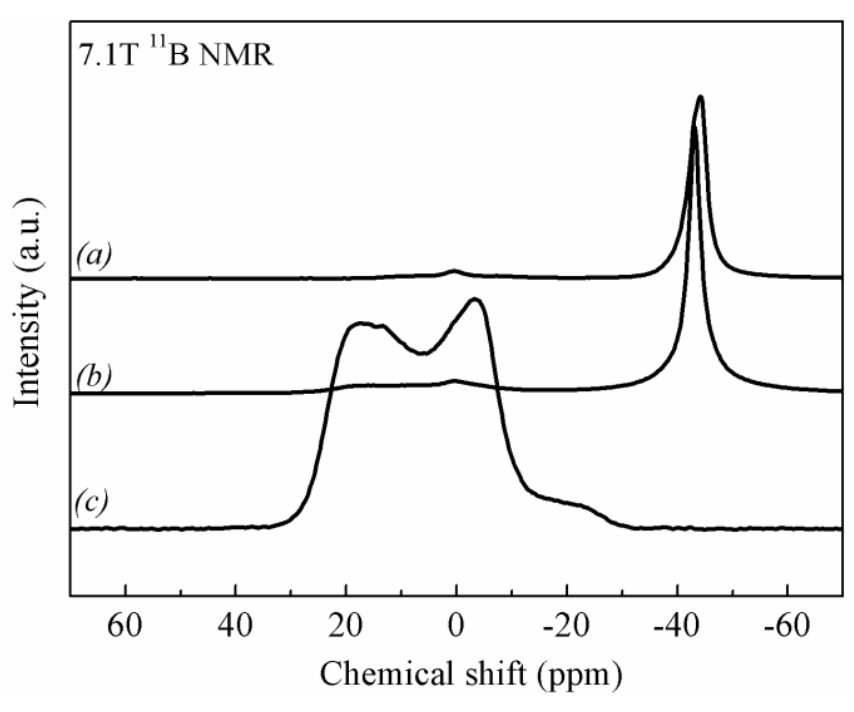

Fig. $6{ }^{11} \mathrm{~B}$ NMR of (a) post-milled $\mathrm{Zn}\left(\mathrm{BH}_{4}\right)_{2} \cdot 2 \mathrm{NH}_{3}$ and following heating to (b) $100{ }^{\circ} \mathrm{C}$ and (c) to $200{ }^{\circ} \mathrm{C}$. The heat

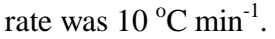

an amorphous phase, at $\mathrm{ca} .69{ }^{\circ} \mathrm{C}$ due to the melting of $\mathrm{Zn}\left(\mathrm{BH}_{4}\right)_{2} \cdot 2 \mathrm{NH}_{3}$. We note that the similar phase change (solid to viscous liquid) is also observed in the dehydrogenation process of $\mathrm{Mg}\left(\mathrm{BH}_{4}\right)_{2} \cdot 2 \mathrm{NH}_{3} \cdot{ }^{20}$ It suggests that with the temperature increase 5 some similar amorphous intermediate(s), e.g. the B-N cleavage, may occur before $\mathrm{H}_{2}$ release in both $\mathrm{Zn}\left(\mathrm{BH}_{4}\right)_{2} \cdot 2 \mathrm{NH}_{3}$ and $\mathrm{Mg}\left(\mathrm{BH}_{4}\right)_{2} \cdot 2 \mathrm{NH}_{3}$. As the temperature increases further the psuedomolecular structure of $\mathrm{Zn}\left(\mathrm{BH}_{4}\right)_{2} \cdot 2 \mathrm{NH}_{3}$ continues to decompose and the intensity of the $\mathrm{Zn}$ peaks increase until they 10 reach a maximum at around $110{ }^{\circ} \mathrm{C}$. Decomposition of $\mathrm{Zn}\left(\mathrm{BH}_{4}\right)_{2} \cdot 2 \mathrm{NH}_{3}$ with hydrogen release starts at $\mathrm{ca} .90{ }^{\circ} \mathrm{C}$; no crystalline phases are observed, however, an amorphous form of $\mathrm{Zn}\left(\mathrm{BH}_{4}\right)_{2} \cdot 2 \mathrm{NH}_{3}$ may be an intermediate phase and $\mathrm{Zn}$ is therefore the only crystalline product in this $\mathrm{H}_{2}$-desorption process. It is 15 worth noting that the role of $\mathrm{LiCl}$ in the dehydrogenation of $\mathrm{Zn}\left(\mathrm{BH}_{4}\right)_{2} \cdot 2 \mathrm{NH}_{3}$ has yet to be demonstrated or ruled out; however, this investigation relies on developments in phase separation and sample purification. It is believed that the imperceptible changes in peak intensity and width pertaining to ${ }_{20} \mathrm{LiCl}$ in the in-situ XRD patterns may imply that there is no interaction between $\mathrm{Zn}\left(\mathrm{BH}_{4}\right)_{2} \cdot 2 \mathrm{NH}_{3}$ and $\mathrm{LiCl}$.

The fact that only $\mathrm{Zn}$ can be observed for the decomposed $\mathrm{Zn}\left(\mathrm{BH}_{4}\right)_{2} \cdot 2 \mathrm{NH}_{3}$ (Figure 5) indicates that any other decomposition products which may have formed could only be present as 25 amorphous phases. FTIR results reveal that, all of the B-H bonds, including $\mathrm{B}-\mathrm{H}$ bending and stretching modes, are almost undetectable for the decomposed $\mathrm{Zn}\left(\mathrm{BH}_{4}\right)_{2} \cdot 2 \mathrm{NH}_{3}$ (Figure 2), while the other signals, including $\mathrm{Zn}-\mathrm{H}, \mathrm{N}-\mathrm{H}$ and $\mathrm{Zn}-\mathrm{N}$, occur at the same position but decrease in intensity. The surviving 30 absorption peaks imply that the final amorphous compound should consist of $\mathrm{Zn}-\mathrm{H}, \mathrm{N}-\mathrm{H}$ and $\mathrm{Zn}-\mathrm{N}$ bonds. The solid-state ${ }^{11} \mathrm{~B}$ NMR results provided some additional valuable hints in the composition evolution and hydrogen release process of $\mathrm{Zn}\left(\mathrm{BH}_{4}\right)_{2} \cdot 2 \mathrm{NH}_{3}$. Figure 6 shows ${ }^{11} \mathrm{~B} \mathrm{NMR}$ results for the as35 prepared sample which reveal a primary boron species with a chemical shift of $-44.1 \mathrm{ppm}$; this is assigned to the boron nucleus in the tetrahedral $\mathrm{BH}_{4}{ }^{-}$units. ${ }^{47}$ Meanwhile, one comparatively weak peak is observed at $0.4 \mathrm{ppm}$, indicating that detectable changes occurred in the chemical environment of the $\mathrm{B}$ atoms 40 compared to the $\mathrm{BH}_{4}^{-}$molecules derived through mechanical milling. This, again, suggests the possibility of partial decomposition of $\mathrm{Zn}\left(\mathrm{BH}_{4}\right)_{2} \cdot 2 \mathrm{NH}_{3}$ (see Figure S7). After heat treatment to $100{ }^{\circ} \mathrm{C}$, one weak peak at $15.0 \mathrm{ppm}$ was observed along with the peak of $0.4 \mathrm{ppm}$ (see Figure S7). The appearance 45 of these two weak peaks suggests that the chemical environment of fractional $\mathrm{B}$ atom shifts to the lower fields intensively compared to the tetrahedral $\mathrm{BH}_{4}^{-}$since the formation of $\mathrm{HBN}_{2}$ and/or $\mathrm{BN}_{3}{ }^{48}$ In addition, the chemical shift, which is assigned to

Table 1. Summarization of calculated crystal structures and selected atomic distances of $\mathrm{Me}\left(\mathrm{BH}_{4}\right)_{2} \cdot 2 \mathrm{NH}_{3}(\mathrm{Me}=\mathrm{Zn}, \mathrm{Mg}, \mathrm{Ca})$.

\begin{tabular}{|c|c|c|c|}
\hline Crystal system & $\begin{array}{l}\mathrm{Zn}\left(\mathrm{BH}_{4}\right)_{2} \cdot 2 \mathrm{NH}_{3} \\
\text { monoclinic }\end{array}$ & $\begin{array}{l}\mathrm{Mg}\left(\mathrm{BH}_{4}\right)_{2} \cdot 2 \mathrm{NH}_{3} \\
\text { orthorhombic }\end{array}$ & $\begin{array}{l}\mathrm{Ca}\left(\mathrm{BH}_{4}\right)_{2} \cdot 2 \mathrm{NH}_{3} \\
\text { orthorhombic }\end{array}$ \\
\hline Space-group & P 1211 (4) & P b c a (61) & P b c n $(60)$ \\
\hline \multirow[t]{4}{*}{ Cell parameters } & $\mathrm{a}=6.4919 \AA$ & $\mathrm{a}=9.3612 \AA$ & $\mathrm{a}=6.4728 \AA$ \\
\hline & $\mathrm{b}=8.8878 \AA$ & $b=17.9632 \AA$ & $\mathrm{b}=8.2730 \AA$ \\
\hline & $c=6.4625 \AA$ & $c=8.7252 \AA$ & $c=12.4126 \AA$ \\
\hline & $\beta=91.8200^{\circ}$ & & \\
\hline \multirow[t]{5}{*}{ M-H } & 1.887 & 2.026 & 2.414 \\
\hline & 1.897 & 2.058 & 2.469 \\
\hline & 1.956 & 2.191 & 2.515 \\
\hline & 2.590 & 2.655 & 2.987 \\
\hline & 2.623 & 2.663 & 3.089 \\
\hline \multirow[t]{2}{*}{ M-B } & 2.281 & 2.261 & 2.769 \\
\hline & 2.286 & 2.394 & 2.960 \\
\hline \multirow[t]{2}{*}{$\mathrm{M}-\mathrm{N}$} & 2.078 & 2.140 & 2.517 \\
\hline & & 2.142 & \\
\hline \multirow[t]{3}{*}{$\mathrm{H}-\mathrm{H}$} & 1.905 & 2.081 & 2.026 \\
\hline & 2.003 & 2.192 & 2.332 \\
\hline & 2.177 & 2.230 & 2.438 \\
\hline
\end{tabular}


$\mathrm{BH}_{4}^{-}$, is still observed at $-43.1 \mathrm{ppm} .{ }^{47}$ Upon further heating to $200{ }^{\circ} \mathrm{C}$, the peaks corresponding to $\mathrm{HBN}_{2}$ and/or $\mathrm{BN}_{3}$ (observed at $17.4 \mathrm{ppm}$ and $-3.1 \mathrm{ppm}$ ) increased in intensity which coincides with the peak of $\mathrm{BH}_{4}^{-}$diminishing totally (Figure 6c). By 5 combination of the XRD, FTIR, NMR and elementary analysis of the end-products ( $\mathrm{N}$ : $\mathrm{H}$ ratio is 1:1) results, as well as the thermolysis results, the dehydrogenation of $\mathrm{Zn}\left(\mathrm{BH}_{4}\right)_{2} \cdot 2 \mathrm{NH}_{3}$ can be speculated as:

$$
2 \mathrm{Zn}\left(\mathrm{BH}_{4}\right)_{2} \cdot 2 \mathrm{NH}_{3} \rightarrow \mathrm{Zn}+\mathrm{Zn}(\mathrm{BNH})_{2}+13 \mathrm{H}_{2}(2)
$$

10 The calculated weight loss of the Eqn. (2) is ca. 10 wt.\%, 1.1 wt.\% higher than the experimental result, which can be explained by a fraction of decomposition of $\mathrm{Zn}\left(\mathrm{BH}_{4}\right)_{2} \cdot 2 \mathrm{NH}_{3}$ during the ball-milling, demonstrated by the XRD and ${ }^{11} \mathrm{~B}$ NMR results (Figure S2 and Figure S7). From the results above, it is concluded 15 that the dehydrogenation mechanism of $\mathrm{Zn}\left(\mathrm{BH}_{4}\right)_{2} \cdot 2 \mathrm{NH}_{3}$ could be generally traced to the combination of the positive and negative $\mathrm{H}$ atoms from $[\mathrm{NH}]$ and $[\mathrm{BH}]$ sources, respectively. However, On condition that a balanced reaction of $\mathrm{BH}$ and $\mathrm{NH}$ occurs in the $\mathrm{Zn}\left(\mathrm{BH}_{4}\right)_{2} \cdot 2 \mathrm{NH}_{3}$, the final products should remain excessive $\mathrm{BH}$ 20 groups. This is opposite to the IR results, which gives the evidence of residual $\mathrm{NH}$ groups but not $\mathrm{BH}$ groups. Therefore, a $\mathrm{H}$ transfer from $\mathrm{B}$ to $\mathrm{N}$ may occur in $\mathrm{Zn}\left(\mathrm{BH}_{4}\right)_{2} \cdot 2 \mathrm{NH}_{3}$ upon dehydrogenation. Anyhow, the dehydrogenation pathway of ammoniates of $\mathrm{Zn}$-based borohydrides is somewhat different with 25 the other reported AMBs, ${ }^{20-23}$ e.g. $\mathrm{Mg}\left(\mathrm{BH}_{4}\right)_{2} \cdot 2 \mathrm{NH}_{3}$, in which the metal cations in the dehydrogenated products are always bonded to the $\mathrm{BN}$ species.

\section{Electronic structure and chemical bonding analysis}

In order to gain a better understanding of the structure and 30 dehydrogenation properties of $\mathrm{Zn}\left(\mathrm{BH}_{4}\right)_{2} \cdot 2 \mathrm{NH}_{3}$, we compare it with two other similar compounds, which are summarized in Table 1. By comparing the $\mathrm{Me}-\mathrm{H}$ and $\mathrm{Me}-\mathrm{N}(\mathrm{Me}=\mathrm{Ca}, \mathrm{Mg}$ or $\mathrm{Zn})$ interatomic distances of these materials, it is possible to correlate the structural features of these materials with the dehydrogenation 35 performance. The average distance of $\mathrm{Ca}-\mathrm{H}$ in $\mathrm{Ca}\left(\mathrm{BH}_{4}\right)_{2} \cdot 2 \mathrm{NH}_{3}$ is $2.414 \AA$. While in $\mathrm{Mg}\left(\mathrm{BH}_{4}\right)_{2} \cdot 2 \mathrm{NH}_{3}$, that distance is ca. $2.026 \AA$. In $\mathrm{Zn}\left(\mathrm{BH}_{4}\right)_{2} \cdot 2 \mathrm{NH}_{3}$, the average distance is significantly lower, at
$1.887 \AA$. In each case the metal cation is similarly coordinated and the ionic radii of $\mathrm{Ca}^{2+}, \mathrm{Mg}^{2+}$, and $\mathrm{Zn}^{2+}$ are 100,72 and $74 \mathrm{pm}$, 40 respectively. Thus, the hydrogen atoms bonded to boron are expected to show increasing anionic character with decreasing $\mathrm{Me}-\mathrm{H}$ bond distance, in the order of $\mathrm{Ca}\left(\mathrm{BH}_{4}\right)_{2} \cdot 2 \mathrm{NH}_{3}$, $\mathrm{Mg}\left(\mathrm{BH}_{4}\right)_{2} \cdot 2 \mathrm{NH}_{3}$ to $\mathrm{Zn}\left(\mathrm{BH}_{4}\right)_{2} \cdot 2 \mathrm{NH}_{3}$. Thereby, affording $\mathrm{Zn}\left(\mathrm{BH}_{4}\right)_{2} \cdot 2 \mathrm{NH}_{3}$ improved dehydrogenation capacity. The $\mathrm{Zn}-\mathrm{N}$ 45 and $\mathrm{Mg}-\mathrm{N}$ average distances are comparable in $\mathrm{Me}\left(\mathrm{BH}_{4}\right)_{2} \cdot 2 \mathrm{NH}_{3}$ with distances of $2.078 \AA$ and $2.142 \AA$, respectively. While the Ca-N distance is surprisingly long, at $2.517 \AA$, which may contribute to the ammonia detachment under inert atmosphere ${ }^{21}$ and therefore poor dehydrogenation performance.

50 The calculated electronic density of states (DOS) (Figure 7) show all structures have a similar finite energy gap in general ( $\mathrm{Zn}$ $4.8 \mathrm{eV}, \mathrm{Mg} 4.9 \mathrm{eV}, \mathrm{Ca} 5.1 \mathrm{eV}$ ), therefore they all exhibit nonmetallic features. All calculated DOSs show similar features. From the projected DOS plots, it can be seen that the lower 55 valence band $(\mathrm{VB},-16$ to $-10 \mathrm{eV})$ is dominated by $\mathrm{N}$ electrons and $\mathrm{H}$ electrons in all three compounds. The middle VB, (-10 to $5 \mathrm{eV}$ ) is dominated by $\mathrm{N}$ states, $\mathrm{B}$ states and $\mathrm{H}$ states in all three compounds, indicating effective overlapping and forming of very strong bonds. This is consistent with the following analysis of the 60 electron localization function plots, i.e., the high ELF value near $\mathrm{B}-\mathrm{H}$ and N-H atoms. Furthermore, in the upper VB region $(-5$ to $0 \mathrm{eV})$, metal $(\mathrm{Mg}, \mathrm{Ca}, \mathrm{Zn}), \mathrm{B}, \mathrm{N}$ and $\mathrm{H}$ electrons dominate, indicating strongly hybridized B-N-H states, which suggests that metal atoms have some interaction with the surrounding atoms. ${ }_{65} \mathrm{Mg}$ and $\mathrm{Ca}$ electrons have negligible contribution near the Fermi energy, while $\mathrm{Zn}$ elections have a larger contribution. It should be noted that $\mathrm{Zn}$ has high states in the -5 to $-3 \mathrm{eV} \mathrm{VB}$ range, which overlaps with B-N-H states, indicating that $\mathrm{Zn}$ forms bonds with surrounding atoms. This may explain the favorable 70 dehydrogenating properties of $\mathrm{Zn}\left(\mathrm{BH}_{4}\right)_{2} \cdot 2 \mathrm{NH}_{3}$ comparing with $\mathrm{Ca}\left(\mathrm{BH}_{4}\right)_{2} \cdot{ }_{2} \mathrm{NH}_{3}$ and $\mathrm{Mg}\left(\mathrm{BH}_{4}\right)_{2} \cdot 2 \mathrm{NH}_{3}$. In the conduction band (CB), the main contributions are from metal, $\mathrm{B}$ and $\mathrm{H}$ atoms, while $\mathrm{N}$ contributes negligibly to the $\mathrm{CB}$.
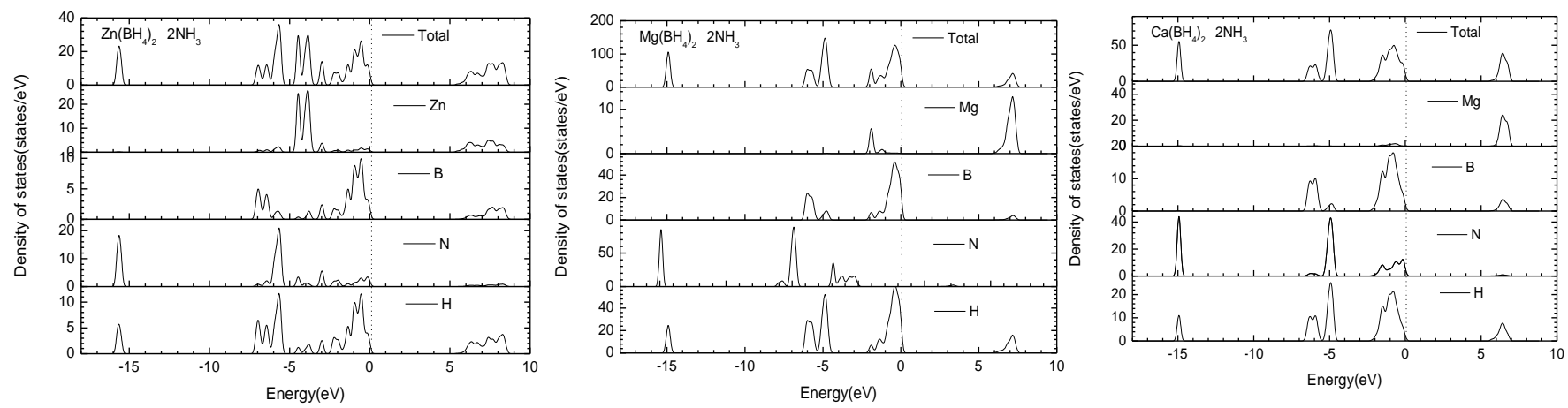

Fig. 7 Electronic density of states for $\mathrm{Zn}\left(\mathrm{BH}_{4}\right)_{2} \cdot 2 \mathrm{NH}_{3}, \mathrm{Mg}\left(\mathrm{BH}_{4}\right)_{2} \cdot 2 \mathrm{NH}_{3}$ and $\mathrm{Ca}\left(\mathrm{BH}_{4}\right)_{2} \cdot 2 \mathrm{NH}_{3}$. Total DOS results are shown for each material, followed by DOS results for $\mathrm{M}, \mathrm{B}, \mathrm{N}$, and $\mathrm{H}$. 

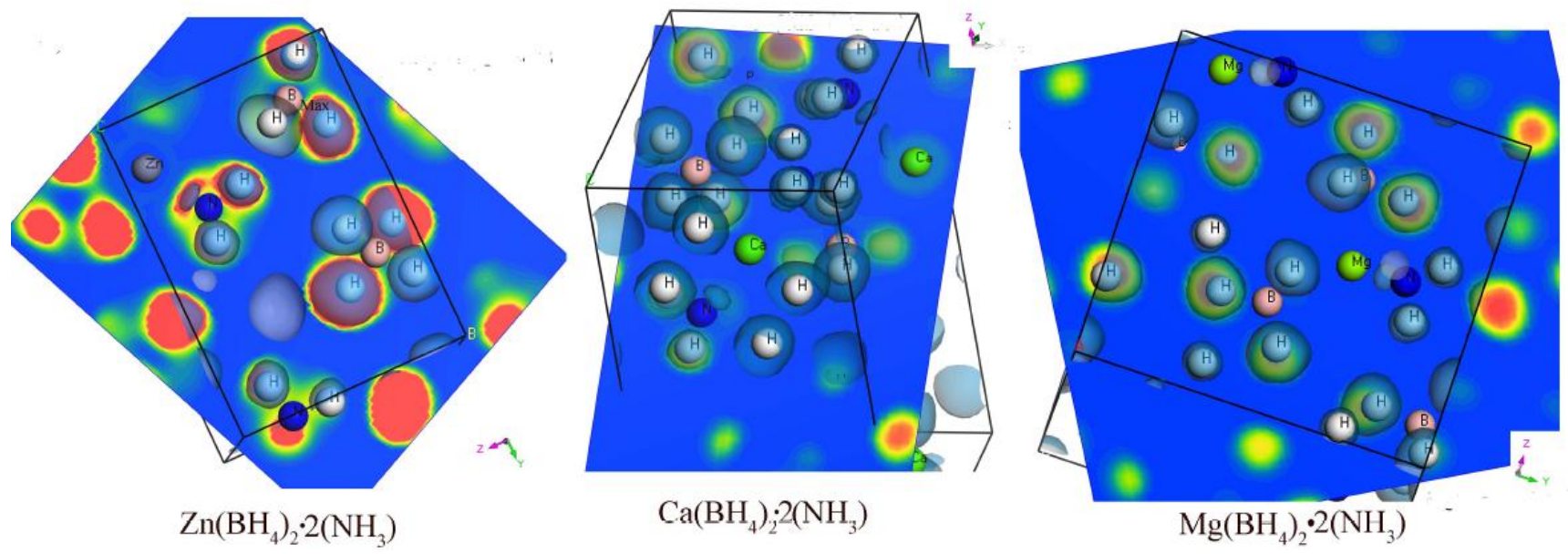

Fig. 8 Electron localization function (ELF $\eta$ ) for $\mathrm{Zn}\left(\mathrm{BH}_{4}\right)_{2} \cdot 2 \mathrm{NH}_{3}, \mathrm{Mg}\left(\mathrm{BH}_{4}\right)_{2} \cdot 2 \mathrm{NH}_{3}$ and $\mathrm{Ca}\left(\mathrm{BH}_{4}\right)_{2} \cdot 2 \mathrm{NH}_{3}$. An isosurface of $\eta=0.15 \mathrm{has}$ been used in all figures, $2 \mathrm{D}$ cross section cut through $\mathrm{M}, \mathrm{B}, \mathrm{N}$, and $\mathrm{H}$ atoms.

Table 2. Summary of dehydrogenation peak temperature $\left(D_{p}\right)$, Pauling electronegativity $\left(\chi_{p}\right)$ and $\mathrm{H}_{2}$ and $\mathrm{NH}_{3}$ evolution for $\mathrm{Zn}\left(\mathrm{BH}_{4}\right)_{2} \cdot 2 \mathrm{NH}_{3}, \mathrm{Mg}\left(\mathrm{BH}_{4}\right)_{2} \cdot 2 \mathrm{NH}_{3}$, and $\mathrm{Ca}\left(\mathrm{BH}_{4}\right)_{2} \cdot 2 \mathrm{NH}_{3}$.

\begin{tabular}{|c|c|c|c|c|}
\hline \multicolumn{2}{|l|}{ Samples } & $\mathrm{Zn}\left(\mathrm{BH}_{4}\right)_{2} \cdot 2 \mathrm{NH}_{3}$ & $\mathrm{Mg}\left(\mathrm{BH}_{4}\right)_{2} \cdot 2 \mathrm{NH}_{3}$ & $\mathrm{Ca}\left(\mathrm{BH}_{4}\right)_{2} \cdot 2 \mathrm{NH}_{3}$ \\
\hline \multicolumn{2}{|l|}{$\chi_{p}$} & 1.65 & 1.31 & 1.0 \\
\hline \multicolumn{2}{|l|}{$D p\left(/{ }^{\circ} \mathrm{C}\right)$} & 127 & $\sim 200$ & $\sim 280^{\mathrm{a}}$ \\
\hline \multirow[t]{2}{*}{$\mathrm{H}_{2}$ released (wt. \%) } & Observed & $8.9^{\mathrm{b}}$ & $12.3 \sim 13.1$ & $12.3^{\mathrm{a}}$ \\
\hline & Calculated & $10.8^{\mathrm{b}}$ & 16 & 13.5 \\
\hline \multirow[t]{2}{*}{$\mathrm{NH}_{3}$ released } & Observed & 0 & $0 \sim 0.8$ & 32.7 \\
\hline & Calculated & 26.4 & 38.6 & 32.7 \\
\hline References & & This paper & 20 & 21 \\
\hline
\end{tabular}

${ }^{a}$ Nearly no hydrogen releases from $\mathrm{Ca}\left(\mathrm{BH}_{4}\right)_{2} \cdot 2 \mathrm{NH}_{3}$ under the dynamic flow mode, and the listed value is obtained as the dehydrogenation of $\mathrm{Ca}\left(\mathrm{BH}_{4}\right)_{2} \cdot 2 \mathrm{NH}_{3}$ conducted in closed vessel under ammonia atmosphere.

${ }^{b}$ The $\mathrm{H}_{2}$-evolution was estimated based on a pure $\mathrm{Zn}\left(\mathrm{BH}_{4}\right)_{2} \cdot 2 \mathrm{NH}_{3}$ sample

In order to further analyse the chemical bonding of the materials, the electron localization function (ELF) has also been calculated as shown in Figure 8. ELF is based on the HartreeFock pair probability of parallel spin electrons and can be 5 calculated in density functional theory from the excess kinetic energy density due to Pauli-repulsion. ${ }^{49}, 50$ This function produces easily understandable, pictorially informative patterns of chemical bonding and is widely used to describe and visualize chemical bonding in molecules and solids. ${ }^{50}$ As described earlier, 10 in the case of $\mathrm{Zn}$ or $\mathrm{Mg}$ they each directly coordinates with $2 \mathrm{BH}_{4}$ groups and $2 \mathrm{NH}_{3}$ groups, while each $\mathrm{Ca}$ atom directly coordinates with $4 \mathrm{BH}_{4}$ groups and $2 \mathrm{NH}_{3}$ groups nearby. In Figure 8, the distribution of ELF in all structures shows the high ELF value near B-H and N-H atoms. This indicates strongly 15 hybridized valence electrons or closed shell bonds between $\mathrm{B}$ and $\mathrm{H}$ and between $\mathrm{N}$ and $\mathrm{H}$, i.e. covalent bonding. The spherical shell attractors around the $\mathrm{H}$ atoms are highly distorted, indicating $\mathrm{H}$ atoms are seen by the surrounding $\mathrm{H}$ atoms and have strongly localized electrons. The valence shell of the $\mathrm{Mg}$ and $\mathrm{Ca}$ 20 atoms in the crystal structures is nearly spherical and with low ELF value, which indicates delocalized electrons, while the $\mathrm{Zn}$ shell is slightly distorted indicating interaction with nearby atoms. No additional attractors were found in between B and $\mathrm{N}$ atoms. This suggests there is no direct ionic bonding between $\mathrm{B}$ 25 and $\mathrm{N}$ sites; $\mathrm{BH}_{4}$ and $\mathrm{NH}_{3}$ groups are only interacting through bonded $\mathrm{H}$ atoms. A feature of note is that an attractor can be seen in between metal and $\mathrm{N}$ atoms in all structures, which bias toward the $\mathrm{N}$ atom. This can be interpreted as ionic bonding characterization between $\mathrm{NH}_{3}$ groups and metal atoms.

30 The decomposition behaviours of these three materials are summarized in Table 2. It can be seen that almost no hydrogen is released from $\mathrm{Ca}\left(\mathrm{BH}_{4}\right)_{2} \cdot 2 \mathrm{NH}_{3}$ under the dynamic flow mode, and the listed value is obtained as the dehydrogenation of $\mathrm{Ca}\left(\mathrm{BH}_{4}\right)_{2} \cdot 2 \mathrm{NH}_{3}$ conducted in closed vessel under ammonia 35 atmosphere. Favorable dehydrogenation performance is observed in the $\mathrm{Mg}\left(\mathrm{BH}_{4}\right)_{2} \cdot 2 \mathrm{NH}_{3}$, which can release total of $13.1 \mathrm{wt} \% \mathrm{H}_{2}$ before $400{ }^{\circ} \mathrm{C}$. Like $\mathrm{Mg}\left(\mathrm{BH}_{4}\right)_{2} \cdot 2 \mathrm{NH}_{3}$, the calcium analogue has an equivalent number of $\mathrm{BH}_{4}$ and $\mathrm{NH}_{3}$ groups. However, the decomposition of calcium borohydride diammoniate under a flow 40 of inert gas only yields $\mathrm{NH}_{3}$ and later $\mathrm{Ca}\left(\mathrm{BH}_{4}\right)_{2}$; no hydrogen is detected by mass spectroscopy. ${ }^{21}$ When conducting volumetric release measurement in a closed vessel, the $\mathrm{Ca}$ analogue releases 
$\mathrm{H}_{2}$ instead of $\mathrm{NH}_{3}$, after sample melting. It is proposed that in a closed vessel $\mathrm{NH}_{3}$ remains in the vicinity of the $\mathrm{Ca}\left(\mathrm{BH}_{4}\right)_{2}$, and thus increases the chance of interaction with $\mathrm{BH}_{4}$ group. ${ }^{21}$ In the case of $\mathrm{Zn}\left(\mathrm{BH}_{4}\right)_{2} \cdot 2 \mathrm{NH}_{3}, 8.9$ wt.\% hydrogen is released under 5 isothermal conditions at $115{ }^{\circ} \mathrm{C}$ within 10 min without any undesirable $\mathrm{NH}_{3}$ and/or $\mathrm{B}_{2} \mathrm{H}_{6}$ evolved during the decomposition. As summarized in Table 2, it shows that the dehydrogenation temperature of these AMBs is correlated to the Pauling electronegativity $\left(\chi_{\mathrm{p}}\right)$ of metal cations, i.e. increased $\chi_{\mathrm{p}}$ leads to 10 lower decomposition temperature, suggesting that the $\chi_{\mathrm{p}}$ of metal cations may play a crucial role in tuning the dehydrogenation temperature of AMBs. This may be due to more electronegativity of $\mathrm{Zn}$ atoms than that of $\mathrm{Ca}$ and $\mathrm{Mg}$, which contributes to the increased anionic character of $\mathrm{H}$ in $\mathrm{B}-\mathrm{H}$ and cationic character of ${ }_{15} \mathrm{H}$ in $\mathrm{B}-\mathrm{H}$, and thus leading to easier $\mathrm{NH} \cdots \mathrm{HB}$ interaction. Therefore, the fact that the $\mathrm{Zn}\left(\mathrm{BH}_{4}\right)_{2} \cdot 2 \mathrm{NH}_{3}$ exhibited even lower dehydrogenation temperature than $\mathrm{Ca}\left(\mathrm{BH}_{4}\right)_{2} \cdot 2 \mathrm{NH}_{3}$ and $\mathrm{Mg}\left(\mathrm{BH}_{4}\right)_{2} \cdot 2 \mathrm{NH}_{3}$ may attribute to its unique structure characteristic obtained by chemical alteration that incorporates ${ }_{20} \mathrm{NH}_{3}$ with $\mathrm{BH}^{4}$ on a molecular level, which can be detailed as the deliberately introduced dihydrogen bonds and tuned cations electronegativity to adjust the temperature and purity of dehydrogenation. The regularity discussed above may provide further insights into the development of new AMBs with more 25 favourable dehydrogenation performance.

\section{Conclusions}

In summary, $\mathrm{Zn}\left(\mathrm{BH}_{4}\right)_{2} \cdot 2 \mathrm{NH}_{3}$ has been mechanically synthesized via a simple ball-milling method. The crystal structure of $\mathrm{Zn}\left(\mathrm{BH}_{4}\right)_{2} \cdot 2 \mathrm{NH}_{3}$ was solved by high resolution ${ }_{30}$ powder X-ray diffraction which has been supported by evidence from infra-red spectroscopy and $\mathrm{B}^{11} \mathrm{NMR}$. It has been shown, through DSC and MS, that this novel compound is able to release 8.9 wt.\% hydrogen at $115{ }^{\circ} \mathrm{C}$ within $10 \mathrm{~min}$ without any undesirable gas accompanying this release during decomposition, 35 thereby demonstrating the potential of $\mathrm{Zn}\left(\mathrm{BH}_{4}\right)_{2} \cdot 2 \mathrm{NH}_{3}$ for onboard hydrogen storage. Promotion of $\mathrm{H}_{2}$ evolution in $\mathrm{Zn}\left(\mathrm{BH}_{4}\right)_{2} \cdot 2 \mathrm{NH}_{3}$ compared to non-ammonia $\mathrm{Zn}$-base borohydride can be ascribed to the bonded ligand ammonia which is crucial for the prevention of release of $\mathrm{B}_{2} \mathrm{H}_{6}$. Furthermore, by comparing 40 the crystal structures of $\mathrm{Me}\left(\mathrm{BH}_{4}\right)_{2} \cdot 2 \mathrm{NH}_{3}(\mathrm{M}=\mathrm{Zn}, \mathrm{Ca}, \mathrm{Mg})$, it has been shown that $\mathrm{Zn}-\mathrm{H}$ bonding is remarkably shorter in the $\mathrm{Zn}$ analogue, thus leading to increased ionic character of $\mathrm{H}$. A correlation between the decreasing of $\mathrm{M}-\mathrm{H}$ distance and the enhanced dehydrogenation performance has been observed. The 45 DFT calculations show that $\mathrm{Mg}$ and $\mathrm{Ca}$ electrons have negligible contribution near the Fermi energy, while $\mathrm{Zn}$ elections have considerable contribution; indicating that $\mathrm{Zn}$ forms bonding with surrounding $\mathrm{N}$ and $\mathrm{H}(\mathrm{B})$ atoms, which leads to the increasing reactivity of $\mathrm{H}^{\delta-}$ in $\mathrm{Zn}\left(\mathrm{BH}_{4}\right)_{2} \cdot 2 \mathrm{NH}_{3}$.The observations of this ${ }_{50}$ research demonstrate that the adduct of $\mathrm{NH}_{3}$, which is close to $\mathrm{BH}_{4}^{-}$in molecular level, is an effective chemical approach for lowering the dehydrogenation temperature and restraining the emission of borane from metal borohydrides. Our findings provide useful insights and guidelines for the design and 55 synthesis of novel AMBs for hydrogen storage.

\section{Acknowledgements}

This work was partially supported by the National Natural Science Foundation of China (Grant No. 51071047), the PhD Programs Foundation of Ministry of Education of China 60 (20090071110053), the Program for New Century Excellent Talents in Universities (NCET-08-0135) Part of this research was undertaken on the Powder Diffraction beamline at the Australian Synchrotron, Victoria, Australia. FWZ would like to thank the $\mathrm{NCI}$ and iVEC for computational resources.

\section{${ }_{65}$ Notes and references}

${ }^{a}$ Department of Materials Science, Fudan University, Shanghai 200433 , China. Fax: +86-21-65643685; Tel: +86-21-55664581; E-mail: yuxuebin@fudan.edu.cn

${ }^{b}$ Australian Synchrotron, 800 Blackburn Rd, Clayton 3168, Australia $70{ }^{c}$ Nanochemistry Research Institute, Perth 6845, Curtin University

$\dagger$ Electronic Supplementary Information (ESI) available: [Crystallographic details, XRD, MS, NMR, DSC, FTIR, and TPD results, including Figures S1-S7 and Tables S1-S4.]. See DOI: $10.1039 / \mathrm{b} 000000 \mathrm{x} /$

751 L. Schlapbach, A. Zuttel, Nature 2001, 414, 353

2 S. I. Orimo, Y. Nakamori, J. R. Eliseo, A. Zuttel, C. M. Jensen, Chem. Rev. 2007, 107, 4111.

3 B. Bogdanovic, M. Felderhoff, S. Kaskel, A. Pommerin, K. Schlichte, F. Schuth, Adv. Mater. 2003, 15, 1012.

804 W. Grochala, P. P. Edwards, Chem. Rev. 2004, 104, 1283.

5 W. George, M. S. D. Crabtree, V. B. Michelle, Phys. Today 2004. 57, 39.

6 A. Klerke, C. H. Christensen, J. Norskov, T. Vegge, J. Mater. Chem. 2008. 18, 2304.

857 A. Zuttel, S. Rentsch, P. Fischer, P. Wenger, P. Sudan, P. Mauron, C. Emmenegger, J. Alloys Compd. 2003, 356, 515; (b) P. Mauron, M. Bielmann, A. Remhof, A. Zuttel, J. H. Shim, Y. W. Cho, J. Phys. Chem. C 2010, 114, 16801; (c) P. Mauron, F. Buchter, O. Friedrichs, A. Remhof, M. Bielmann, C. N. Zwicky, A. Zuttel, J. Phys. Chem. B 2008, 112, 906.

8 K. Chlopek, C. Frommen, A. Leon, O. Zabara, M. Fichtner, J. Mater. Chem. 2007, 17, 3496.

9 H. R. Hoekstra, J. J. Katz, J. Am. Chem. Soc. 1949, 71, 2488.

10 Y. Nakamori, K. Miwa, A. Ninomiya, H. W. Li, N. Ohba, S. I. 95 Towata, A. Zuttel, S. I. Orimo, Phys. Rev. B 2006, 74, 045126.

11 A. B. Burg, H. I. Schlesinger, J. Am. Chem. Soc. 1940, 62, 3425.

12 (a) O. Friedrichs, A. Borgschulte, S. Kato, F. Buchter, R. Gremaud, A. Remhof, A. Zuttel, Chem. Eur. J. 2009, 15, 5531. (b) R. B. S. Narashimhan, Aldrichim. Acta. 1998, 31, 19.

10013 M. B. Gilbert, A. K. Douglas, H. S. Joachim,H. I. Ralph, M. S. Robert III., 2007; available at: http://www.hydrogen.energy.gov/pdfs/review07/stp_24_brown.pdf.

14 (a) J. J. Vajo, S. L. Skeith, F. Mertens, J. Phys. Chem. B 2005, 109, 3719; (b) J. J. Vajo, W. Li, P. Liu, Chem. Comm. 2010, 46, 6687; (c) J. J. Vajo, F. Mertens, C. C. Ahh, R. C. Bowman, B. Fultz, J. Phys. Chem. B 2004, 108, 13977.

15 A. F. Gross, J. J. Vajo, S. L. Van Atta, G. L. Olson, J. Phys. Chem. C 2008, 112, 5651.

16 Z. T. Xiong, G. T. Wu, H. J. Hu, P. Chen, Adv. Mater. 2004, 16, $110 \quad 1522$.

17 (a) F. E. Pinkerton, G. P. Meisner, M. S. Meyer, M. P. Balogh, M. D. Kundrat, J. Phys. Chem. B 2005, 109, 6; (b) F. E.; Pinkerton, M. S. Meyer, J. Alloy. Compd. 2008, 464, L1; (c) F. E. Pinkerton, M. S. Meyer, G. P. Meisner, J. Alloy. Compd. 2007, 433, 282.

11518 H. L. Chu, Z. T. Xiong, G. T. Wu, J. P. Guo, T. He, P. Chen, Dalton. Trans. 2010, 39, 10585.

19 A. Gutowska, L. Li, Y. Shin, C. M. Wang, X. S. Li, J. C. Linehan, R. S. Smith, B. D. Kay, B. Schmid, W. Shaw, M. Gutowski, T. Autrey, Angew. Chem. Int. Ed. 2005, 44, 3578. 
20 G. Soloveichik, J. H. Her, P. W. Stephens, Y. Gao, J. Rijssenbeek, M. Andrus, J. Zhao, C. Inorg. Chem. 2008, 47, 4290.

21 H. L. Chu, G. T. Wu, Z. T. Xiong, J. P. Guo, T. He, P. Chen, Chem. Mater. 2010, 22, , 6021.

522 Y. H. Guo, G. L. Xia, Y. H. Zhu, L. Gao, X. B. Yu, Chem. Commun. 2010, 46, 2599.

23 Y. H. Guo, W. W. Sun, Z. P. Guo, H. K. Liu, D. L. Sun, X. B. Yu, J. Phys. Chem. C 2010, 114, 12823.

24 (a) Y. H. Guo, X. B. Yu, W. W. Sun, D. L. Sun, W. N. Yang, Angew. Chem. Int. Ed. 2011, 50. 1087. (b) Y. H. Guo, H. Wu, W. Zhou, X. B.Yu, J. Am. Chem. Soc. 2011, 133, 4690.

25 R. Z. Sørensen, J. S. Hummelshøj, A. Klerke, J. B. Reves, T. Vegge, J. K. Nørskov, C. H. Christensen, J. Am. Chem. Soc. 2008, 130, 8660.

1526 L. Gao, Y. H. Guo, G. L. Xia, X. B. Yu, J. Mater. Chem. 2009, 19, 7826.

27 L. Gao, Y. H. Guo, Q. Li, X. B. Yu, J. Phys. Chem. C 2010, 114, 9534.

28 E. Jeon, Y. Cho, J. Alloys Compd. 2006, 422, 273.

2029 S. Srinivasan, D. Escobar, Y. Goswami, E. Stefanakos, Int. J. Hydrogen Energy 2008, 33, 2268.

30 T. Nakagawa, T. Ichikawa, Y. Kojima, H. Fujii, Mater. Trans. 2007, 3,556 .

31 A. B. E.Zirngiebl, W. Ger. Pat. 1959, 070, 148.

2532 T. Yamaguchi, O. Lindqvist, Acta Chem. Scand. 1981, 35, 727.

33 K. S. W. B. J. K. D. Wang, AIP Conf. Proc. 2007, 879, 879.

34 A. Bergamaschi, A. Cervellino, R. Dinapoli, F. Gozzo, B. Henrich, I. Johnson, P. Kraft A. Mozzanica, B. Schmitt, X. Shi, J. Synchrot. Radiat. 2010, 17, 653.

3035 S. J. Clark, M. D. Segall, C. J. Pickard, P. J. Hasnip, M. J. Probert, K. Refson, M. C. Payne, Z. Kristall. 2005, 220, 567.

36 M. D. Segall, P. J. D. Lindan, M. J. Probert, C. J. Pickard, P. J. Hasnip, S. J. Clark, M. C. Payne, J. Phys.: Condens Matter 2002, $14,2717$.

3537 J. P. Perdew, K. Burke, M. Ernzerhof, Phys. Rev. Lett. 1996, 77, 3865.

38 B. G. Pfrommer, M. Cote, S. G. Louie, M. L. Cohen, J. Comput. Phys. 1997, 131, 233.

39 T. J. Marks, J. R. Kolb, Chem. Rev. 1977, 77, 263.

4040 D. L. A. Boultif, J. Appl. Crystallogr. 1991, 24, 987.

41 Favre-Nicolin, V.; Cerny, R. J. Appl. Cryst. 2002, 35, 734.

42 Bruker AXS (2008): TOPAS V4.2: General profile and structure analysis software for powder diffraction data. - User's Manual, Bruker AXS, Karlsruhe, Germany.

4543 R. D. Shannon, Acta Crystallogr., Sect. A 1976, 32, 751.

44 D. Ravnsbaek, Y. Filinchuk, Y. Cerenius, H. J. Jakobsen, F. Besenbacher, J. Skibsted, T. R. Jensen, Angew. Chem. Int. Ed. 2009, $48,6659$.

45 G. Wolf, J. Baumann, F. Baitalow, F. P. Hoffmann, Thermochim. $50 \quad$ Acta 2000, 343, 19.

46 A. D. Sutton, A. K. Burrell, D. A. Dixon, E. B. Garner III, J. C. Gordon, T. Nakagawa, K. C. Ott, J. P. Robinson, M. Vasiliu, Science 2011, 331, 1426.

47 S. J. Hwang, R. C. Bowman, J. W. Reiter, J. Rijssenbeek, G. L.

55 Soloveichik, J. C. Zhao, H. Kabbour, C. C. Ahn, J. Phys. Chem. C $2008,112,3164$.

48 C. Gervais, J. Maquet, F. Babonneau, C. Duriez, E. Framery, M. Vaultier, P. Florian, D. Massiot, Chem. Mater. 2001, 13, 1700.

49 M. K. P. Kohout, F. R. Wagner, Y. Grin, Theor. Chem. Acc. 2004, $112,453$.

50 For ELF calculation details please see: http://www.cpfs.mpg.de/ELF. 